\title{
The Will to Integrate: South Africa's Responses to Regional Migration from the SADC Region*
}

\author{
Christopher Changwe Nshimbi and Lorenzo Fioramonti**
}

\begin{abstract}
This paper surveys frameworks of labour migration in southern Africa and determines South Africa's policy responses to inflows of migrants from seven neighbouring countries. Legislations, policy reports and scientific publications on migration were thoroughly reviewed and interviews and correspondence with key policymakers were conducted. Statistical analyses of data on foreign worker recruitments and permits issued by South Africa's Department of Home Affairs were also performed. The absence of a migration protocol in southern Africa suggests SADC Members have not implemented the African Union's migration policy basic guidelines. Two systems coexist in southern Africa that complicate migration governance: a South Africa-managed bilateral migration policy, and aspirations for a formal SADC-managed migration policy. Bilateral agreements between South Africa and neighbours have established a labour migration system that dims prospects for a regional migration policy. SACU Members could establish a two-tier policy to achieve free movement while maintaining managed migration policy outside SACU. An official multilateral migration governance mechanism would serve SADC better than the current ad-hoc measures.
\end{abstract}

\section{Introduction}

There were 214 million international migrants in 2010, compared to 155 million in 1990 (UN, 2012). From the total global increase of 59 million international migrants between 1990 and 2010, the number living in the Global North increased by 46 million and those in the Global South by 13 million (UNDESA, 2012). Twenty-nine million of the 214 million migrants registered in 2010 were Africans, and their major destination was Africa itself (Table 1). The majority of these African migrants remained in the major area of their birth. UNDESA (2009) estimated the number of international migrants in Southern Africa in 1990 and 2010 at 1.4 million and 2.2 million, respectively, representing a proportional increase from 3.4 per cent to 3.7 per cent in southern Africa's total population.

International migrants increased partly due to liberalization in southern Africa, as people migrate in search of better economic opportunities. Individuals who migrate following globalization are generally better off regarding poverty than non-migrants (Onyeiwu et al., 2008). Conflict motivates others to migrate while some migrate clandestinely as local herdsmen, and as members of ethnic groups, whose domicile straddles southern Africa's 'artificial' state boundaries.

\footnotetext{
*This paper is based on wider research conducted by the Migration for Work Consortium (MiWORC), comprising academic (GovInn, University of Pretoria; United Nations University Institute on Comparative Regional Integration Studies; UNESCO Chair on Free Movement), South African Government (Department of Labour; South African Local Government Association; Statistics South Africa), and international (ILO; IOM) partners. The European Union, in the framework of the EU-South Africa Dialogue Facility (EuropeAid/132200/L/ACT/ZA), funded part of the research. The opinions expressed in the paper, however, belong solely to the authors and do not necessarily reflect the opinions of the member groups of MiWORC, the EU or Government of South Africa. Comments are welcomed and should be directed to the authors: csnzed@gmail.com. The authors wish to thank participants in the Institutional Integration and Policy Coordination session of the African Economic Conference Johannesburg, South Africa, 28-30 October 2013 for valuable comments and contributions.

${ }^{* *}$ Christopher Changwe Nshimbi, Post-doctoral Research Fellow, Centre for the Study of Governance Innovation (GovInn), Department of Political Sciences, University of Pretoria. Lorenzo Fioramonti, Associate Professor and Jean Monnet Chair in Regional Integration and Governance Studies, Director of the Centre for the Study of Governance Innovation (GovInn), Department of Political Sciences, University of Pretoria.
} 
Table 1: International migrants by origin and country, 2010 (millions)

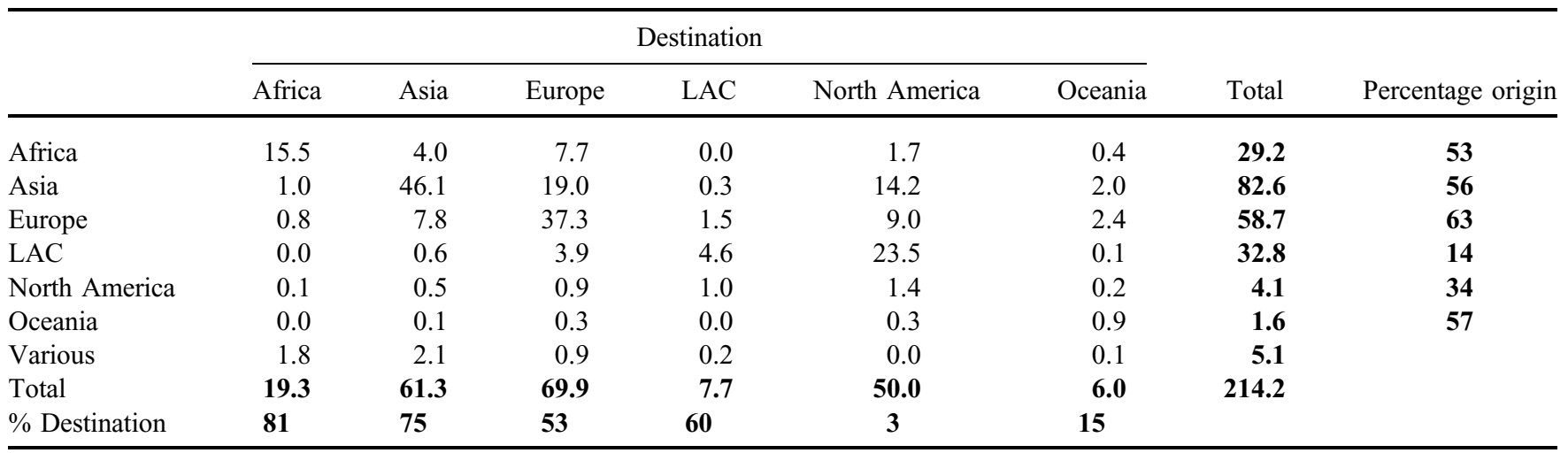

Note: LAC stands for Latin America and the Caribbean.

Source: United Nations Department of Economic and Social Affairs (2012).

\subsection{Problematizing Labour Migration in Southern Africa}

Nshimbi and Fioramonti (2013, p. 50) review existing regional attempts to manage labour migration in key regions of the world and highlight several implications for regional integration and migration governance in southern Africa.

- A region's level of economic development and the degree of similarity of economic development of neighbouring countries within the region shape the ease with which it can handle cross-border labour mobility. Even in cases of similar development levels within a region (e.g. EU), governments have been allowed to slow the pace at which full integration of labour markets occurs.

- Some policies within a region clearly aim at complete free movement for citizens and others at managed migration of specific categories of workers.

- Many regional labour market regimes focus on skilled migration and link this to the recognition of qualifications. The EU and other regions have been able to facilitate labour migration from within, while acting as a regional 'fortress' against thirdcountry nationals by separating out policies on free movement of citizens and formal workers from the regulations covering movements of asylum seekers and refugees.

- The EU is exceptional in the way it has evolved its regional migration governance policies and system from free movement of labour to EU citizenship and associated benefits and rights to work and establishment.

- ECOWAS has the most advanced and best-implemented migration regime in Africa, with categorical legislation and evident commitment to free movement of labour, as an essential element to the Common Market goal.

SADC's economic integration project has significantly progressed regarding movement of goods and services. Partly helped by the liberalization in the 1980s and early 1990s, most members have also reduced trade tariffs consistent with the SADC Protocol on Trade according to SADC's tariff phase-down schedule. Despite non-tariff barriers (NTB) remaining a major obstacle to deepening SADC integration, SADC has fulfilled minimum conditions for a free trade area (FTA). SADC is yet to fulfil its Customs Union goal, initially targeted for 2010. Consequently, SADC has defaulted on the comprehensive regional integration roadmap, which should have taken SADC through an FTA, customs union, common market and monetary union to a SADC economic union by 2018 (SADC Regional Indicative Strategic Development Plan, 2003). Trade wise, therefore, SADC has to regulate its business environment further and address specific integration deepening issues such as facilitate investments, trade, intellectual property rights and competition policy. An enhanced regional investment climate, for example, would improve prospects for regional labour. Investment has been shown to indirectly increase multinational employment (Asiedu and Gyimah-Brempong, 2008). The drawback SADC faces in deepening integration is compounded by SADC being the only regional economic community (REC) in Africa that has 'refused to endorse the general idea of free movement of persons within the community' (Oucho and Crush, 2001, p. 142). Therefore, what systems define regional labour migration in southern Africa? 


\subsection{Objectives}

An overview of labour migration policies in southern Africa addresses this question through a comparative analysis of a subset of SADC countries and specifically by:

- investigating existing policies and related similar regional or bilateral frameworks pertaining to labour migration in southern Africa and, particularly, labour migration originating from Namibia, Botswana, Lesotho, Swaziland, Zimbabwe, Mozambique and Malawi and directed towards South Africa; and

- analysing South Africa's policy responses to inflows of migrants from these seven countries.

The key questions arising from these objectives include:

- What are the prevalent form(s) of regional labour migration governance in southern Africa?

- What is the degree of 'regionalism' permeating national labour migration legislation in the SADC region?

- What labour migration pacts exist between SADC states at the bilateral level?

- How do specific bilateral agreements between South Africa and neighbouring countries impact regional labour migration?

- At the national level, do legislations and policies on labour and migration build on any SADC framework or do they have any regional considerations in their formulation?

\subsection{Methodology}

Primary data for the analysis included a thorough review of relevant regional and national legislations and interviews and correspondence with key policymakers in South Africa. Focus group discussions were also held. The respondents selected for interviews were chosen on the basis of their policy portfolio and position within the relevant organizations. Secondary data included policy reports and scientific publications on the topic. Data on recruitments of foreign workers and on various types of permits issued by South Africa's Department of Home Affairs (DHA) was also used to perform statistical analyses aimed at answering the research questions. Countries were selected based on geographical proximity and relevance to the South African labour market. All seven countries, except Malawi, share borders with South Africa. These countries have also traditionally supplied migrant labour to South Africa, especially in the mining and agricultural sectors.

Following this introduction, Section 2 discusses migration governance in Africa, including the African Union's (AU) position on migration. Section 3 narrows on southern Africa and reviews policies and regional and bilateral labour migration frameworks in the SADC and labour 'migration' policies in South Africa, with a specific emphasis on migrants coming from South Africa's neighbours. Section 4 discusses the issues arising. Section 5 concludes.

\subsection{Labour Migration and Regional Integration}

An issue for review in the context of regional labour migration is the distinction between free movement of people and free movement of labour. From a regional integration perspective and the implied goal of Common Markets, freedom of movement implies one of four freedoms: free movement of capital, persons, goods and services. In the EU, for example, free movement of these factors is enshrined in the EC Treaty, constitutes a fundamental principle of the EU and forms the basis of the Single Market. However, freedom of movement connotes more the free movement of workers than of people in general when discussed in the context of the Single Market (Nita, forthcoming). This is true of the European project, where the use and application of free movement gradually evolved from fundamentally connoting the free movement of workers to the free movement of people in general. The Maastricht Treaty introduced European citizenship and lifted most internal border controls between EU members and brought with it the right for all member state citizens to live and move freely within the EU.

\section{Labour Migration Governance in Africa}

The AU envisages an African Economic Community (AEC) and recognizes eight African regional economic communities (RECs) as pillars for building the EAC (AU, 2012). ${ }^{1}$ Member states should gradually remove, among themselves, 'obstacles to 
the free movement of persons, goods, services and capital and the right of residence and establishment' (Paragraph 2(i) Article 4, Abuja Treaty). Accordingly, Africa shall be an Economic Community by 2028. Article 6(e) of the Abuja Treaty details four activities for establishing the African Common Market (ACM). Activity 6(e)(iii) provides for the application of the principle of free movement of persons and the rights of residence and establishment. Article 71(e) urges AU members to cooperate towards developing, planning and employing human resources by adopting employment policies that allow persons to move freely within the Community through strengthening and establishing labour exchanges that facilitate the employment of available skilled manpower of one member state in other AU states where such manpower shortages exist.

The Migration Policy Framework for Africa (MPFA) and the African Common Position on Migration and Development (ACPMD) define the AU's approach to migration in Africa (African Union, 2006a, 2006b). The MPFA emphasizes the critical role of migration in development and encourages members and African RECs to formulate policies to manage and harness migration for continental development. However, the framework is not legally binding but a reference document from which RECs and AU members can borrow issues useful and applicable to their respective migration situations. The ACPMD encourages national, continental and international action and prioritization of migration-related policy issues and recommendations.

Policy and activity coordination and harmonization, besides progressive integration of Africa's RECs is critical to establishing the AEC. Hence the AU and RECs adopted a Protocol on Relations between the African Economic Community and the Regional Economic Communities in 1998. RECs can cooperate, coordinate and harmonize policies with other RECs in Africa within this framework. Member states of the Common Market for Eastern and Southern Africa (COMESA), the East African Community (EAC) and SADC thus agreed to expedite the establishment of a Tripartite FTA (TFTA) comprising the three RECs at the 2008 COMESA-ECA-SADC Tripartite (CEST) Summit in Uganda. The Summit reviewed and agreed on, among others, a programme to harmonize trading arrangements amongst the RECs, free movement of people and institutional arrangements on the basis of which the RECs would foster cooperation (COMESA-EAC-SADC Tripartite, 2012). The first CEST Summit in 2005 had sought stronger and deeper eastern and southern African economic integration. CEST is yet to ratify the TFTA.

The January 2012 AU Summit 'boosting intra-African trade' endorsed the CEST FTA and identified it as a critical element in the AU's roadmap to a Continental Free Trade Area (CFTA) by 2017. Until the AU roadmap is implemented and a continental or, indeed, the TFTA established, however, African RECs remain disparate and prompt the question, to what extent do African RECs contribute to the AU goal of continental integration? Have the RECs progressed towards free movement of persons and, therefore, Africa's integration? The review of existing labour migration legislation and policies in the SADC, as one of the eight RECs the AU has identified to build the AEC, elucidates Africa's whereabouts regarding the continental economic community.

\section{Labour Migration Governance in the SADC}

International migrants have long circulated southern African, driven by work, conflict and trade, etc. The organized labour migration system that came with the discovery of gold on the Witwatersrand in the $1880 \mathrm{~s}$ was preceded by large-scale migration to the diamond fields in Kimberly in the 1860s. Thus the South African Chamber of Mines established the Rand Native Labour Association, among others, which institutionalized labour migration (from the rest of southern Africa to South Africa). Mozambique, Botswana, Lesotho, Malawi and Swaziland supplied most of the unskilled labour to South African mines. The migrant labour system thus established defined patterns of migration in southern Africa, even in the post-independence era. In the 1960s and 1970s copper-rich Zambia and diamond-rich Botswana too attracted migrants from southern Africa. Liberation struggles and post-independence conflict in southern Africa added to forced migration. Mozambique, Zimbabwe and Angola, for example, still under minority rule then, produced refugees who migrated to Botswana, Tanzania and Zambia. Many South Africans and Namibians too lived in exile in southern Africa during apartheid.

With 15 members, SADC started out in April 1980 with nine countries as the Southern African Development Co-ordinating Conference (SADCC). ${ }^{2}$ Then Front Line States (FLS) movement established SADCC to reduce members' dependence on apartheid South Africa. In 1992 SADCC changed into SADC, when members signed the SADC Declaration and Treaty (SADC Treaty) in Windhoek, Namibia. When apartheid ended, SADC shifted from focusing on development for countering South Africa, to fostering southern Africa's socioeconomic integration. SADC seeks an economic union through the successive stages of regional integration - FTA, customs union, common market and economic union. This has implications for the regional movement of factors, especially labour. 


\subsection{SADC Instruments on Labour Migration}

The SADC Treaty provides for progressive elimination of, among others, 'obstacles to the free movement ... labour and of the people of the Region generally, among Member States' (SADC Treaty, 1992, p. 6). The Protocol on the Facilitation of Movement of Persons in SADC (hereafter Facilitation Protocol) implements this provision of the SADC Treaty (Article 10.3). The Protocol promotes the AU's aspirations for free movement of persons in African RECs as a stepping-stone towards the AEC (Protocol on the Facilitation of Movement of Persons in SADC, 2005, p. 1).

SADC started pushing for free movement in the 1990s. The 1995 Draft Protocol on Free Movement of Persons in SADC targeted free regional movement for SADC citizens over a 10-year period. The protocol would confer on SADC citizens the right to free entry, residence and establishment of oneself in the territory of another member state. The prospect of complete abolition of border controls on people's movements within SADC did not bode well with some members. South Africa, Botswana and Namibia in particular declined to support this Protocol, which was consequently dropped. SADC Secretariat redrafted and accommodated the concerns SADC governments had raised over the 1995 Protocol. Governments approved the redrafted version named the 2005 Draft Protocol on the Facilitation of Movement of Persons in SADC. Overall, the Facilitation Protocol progressively eliminates obstacles to the movement of SADC citizens within the territories of member states. It provides SADC citizens visa-free entry into second SADC countries, for lawful purposes and for a maximum period of three months, and in keeping with the laws of the member state they are entering (SADC, 2012a). Currently only six SADC members - Botswana, Lesotho, Mozambique, South Africa, Swaziland and Zambia - have ratified the Facilitation Protocol. The Protocol is, therefore, not in force because SADC has not reached the required minimum of two-thirds of ratifications. SADC, therefore, currently lacks a formal framework governing regional migration. National laws regulate labour migration throughout the SADC territories. SADC states, however, enter into labour migration-related bilateral agreements with one another. Such agreements dampen prospects of ratifying the Facilitation Protocol as some SADC members might find the agreements a desirable alternative to the regional migration regime the Facilitation Protocol seeks to establish.

Other SADC protocols also bear on the regional and member states' migration regimes. The SADC Protocol on Education and Training, for example, facilitates freer movement of students and academic staff within the SADC region for study, teaching and research and, therefore, relaxes and eliminates immigration formalities (Article 3(a)). South African institutions of learning favour SADC citizens in admission of foreigners to the institutions (Director, Africa Bilateral, Department of International Relations and Cooperation (DIRCO), personal interview, 16 November 2012). SADC citizens comprise the largest number of foreign students in South Africa and benefit from a 'special dispensation for SADC students' wherein they pay lower fees than the standard international fees other foreign students pay (Director, Africa Bilateral, ibid.). Accordingly, South Africa's Immigration Act regulates 'the influx [into South Africa] of foreigners and residents to promote economic growth by facilitating the movement of students and academic staff within the SADC for study, teaching and research' (Immigration Act, in Klaaren and Rutinwa, 2004, p. 54). DIRCO's claims are consistent with data on types of temporary residence permits (TRP) South Africa's DHA issued in 2011. Table 3 below shows that the DHA granted more study permits than business and work permits combined to each of African and SADC citizens in 2011. Also, the number of study permits the DHA issued to SADC citizens was more than half those granted to the rest of Africa. Interestingly, even within SADC, the DHA issued more study permits (25 per cent) than for work ( 20 per cent). The SADC Protocol on Trade also allows traders in the region to establish and maintain business presence abroad. SADC 'Member States undertake to permit and facilitate the establishment of cargo, clearing and forwarding offices in their territories by persons, organisations or associations of other Member States or their authorised agents, for the purpose of facilitating transit traffic in accordance with their national laws and regulations' (Protocol on Trade, Article 11.2).

The Employment Bureau of South Africa (TEBA) sources workers domestically and abroad for mining houses and subcontractors that service South Africa's mining industry. Table 2 displays domestically sourced and workers from four SADC countries working in South African mines. Except for Mozambique, the other three together with South Africa constitute the Southern African Customs Union (SACU). Overall, the share of TEBA's foreign recruits in South Africa's mines declined from 32 per cent in 2006 to 22 per cent in 2012, while South African recruits increased from 68 per cent in 2006 to 78 per cent in 2012. Shares of Mozambicans and each of the other SACU states declined. For example, Swaziland's declined from 2.2 per cent in 2006 to 1.4 per cent in 2012 .

Further, cross-border migration even in the SACU is not particularly easy from a legal-institutional point. SACU has a deeper level of economic integration than SADC. SACU states have a common external tariff (CET) towards non-members. All, except Botswana, participate in a common currency area (CMA). However, the labour market in SACU is not liberalized. The SACU 
Table 2: TEBA-recruited mineworkers by country of origin, 2006-2012

\begin{tabular}{cccccccr}
\hline Year & RSA & Lesotho & Botswana & Swaziland & Mozambique & Percentage foreign & Total \\
\hline 2006 & 218,137 & 46,078 & 2,992 & 7,123 & 46,706 & 32 & 321,036 \\
2007 & 225,949 & 45,608 & 2,845 & 7,099 & 44,879 & 31 & 326,380 \\
2008 & 243,701 & 42,851 & 2,654 & 6,397 & 43,004 & 28 & 338,607 \\
2009 & 224,544 & 38,559 & 2,357 & 5,855 & 39,090 & 28 & 310,405 \\
2010 & 228,370 & 35,179 & 1,800 & 5,009 & 35,782 & 25 & 306,140 \\
2011 & 240,896 & 34,583 & 1,783 & 4,779 & 34,940 & 24 & 316,981 \\
2012 & 244,842 & 30,519 & 1,527 & 4,485 & 31,596 & 22 & 312,969 \\
\hline
\end{tabular}

Source: Tim le Roux in Budlender (2013).

Agreement makes no provisions for free regional movement of labour. Alternative instruments such as immigration acts and bilateral agreements between South Africa and other SACU states determine labour movement in SACU.

\subsection{South Africa}

\section{National Legislations and Regional Labour Migration}

Undocumented migrants significantly contribute to the current cross-border labour migration in southern Africa (Mengelkoch, 2001; Oucho and Crush, 2001). This is at odds with SADC's declaration to eliminate obstacles to free flow of, among others, labour. Southern African migrants make South Africa, Botswana and Namibia their most preferred destinations. The three countries hosted approximately 501,000, 10,000 and 35,000 migrants, respectively, in 1990. Migrants rose to approximately 1.2 million, 76,000 and 76,000, for South Africa, Botswana and Namibia, respectively in 2010 (Nshimbi and Fioramonti, 2013, p. 62). Out of the approximately 77,000 TRPs Statistics South Africa analysed for migrants originating from Africa in 2012, approximately 46,000 were issued to SADC citizens (Statistics South Africa, 2013, p. 16).

Immigration Act No. 13 of 2002 specifies conditions for temporary and permanent residence in South Africa. The Act (amended in 2004) provides for 13 types of TRPs: visitors, study, treaty, work, business, crew, medical treatment, relatives, retired persons, corporate, exchange, asylum transit and, cross-border and transit permits. The permits for migrants include a work permit, a corporate permit for companies to source foreign labour and employ foreigners, a business permit for foreigners to run business in South Africa, and a treaty permit.

Table 3 shows that the DHA issued in total 106,173 TRPs in 2011, including business, work, study and other permits combined. The DHA issued the majority of its work permits to overseas applicants ( 57 per cent), followed by applicants from the rest of Africa (42 per cent), and least of all, SADC (31 per cent). Zimbabweans alone received the highest number of all work permits issued in 2011, representing 25 per cent. Consequently, within SADC Zimbabweans top the list of work and, actually, each category of TRPs DHA issued to SADC citizens. This is attributable to two things: the DHA's regularization programme for Zimbabweans who had entered South Africa without official documentation; and the political and economic crisis in Zimbabwe, which has encouraged out migration to South Africa's strong economy. Zimbabweans received half (49.2 per cent) of all TRPs issued to SADC citizens in 2011, followed by Lesotho (8.5 per cent), the Democratic Republic of Congo (DRC) (8.2 per cent), Angola (6.4 per cent) and Malawi (6.4 per cent). The rest received 5 per cent or less each.

Table 4 displays new applications by citizens of SADC countries to the DHA for asylum in 2011. This data underpins the suggestion that political and economic crises in sending countries contribute to citizens' decisions to migrate. Zimbabwean, DRC and Malawian asylum applicants top the list by far (and Zimbabweans farthest) with 80 per cent, 12 per cent and 6 per cent, respectively. The other SADC states share approximately 2 per cent of asylum applications among themselves. The economic and political crisis in Malawi in 2010 might explain the high number of Malawian asylum seekers in South Africa in 2011. Malawi has, however, also traditionally supplied labour to South Africa.

Data on work permits issued from 1990 to 2011 in Table 5 is based on DHA annual reports (Budlender, 2013, p. 31). Except for 2000, 2004 and 2010, this data suggests the issuance of new permits generally trended upwards over this period. The opposite applies to work permit renewals (where data is available). 
Table 3: Temporary residence permits (type and country), 2011

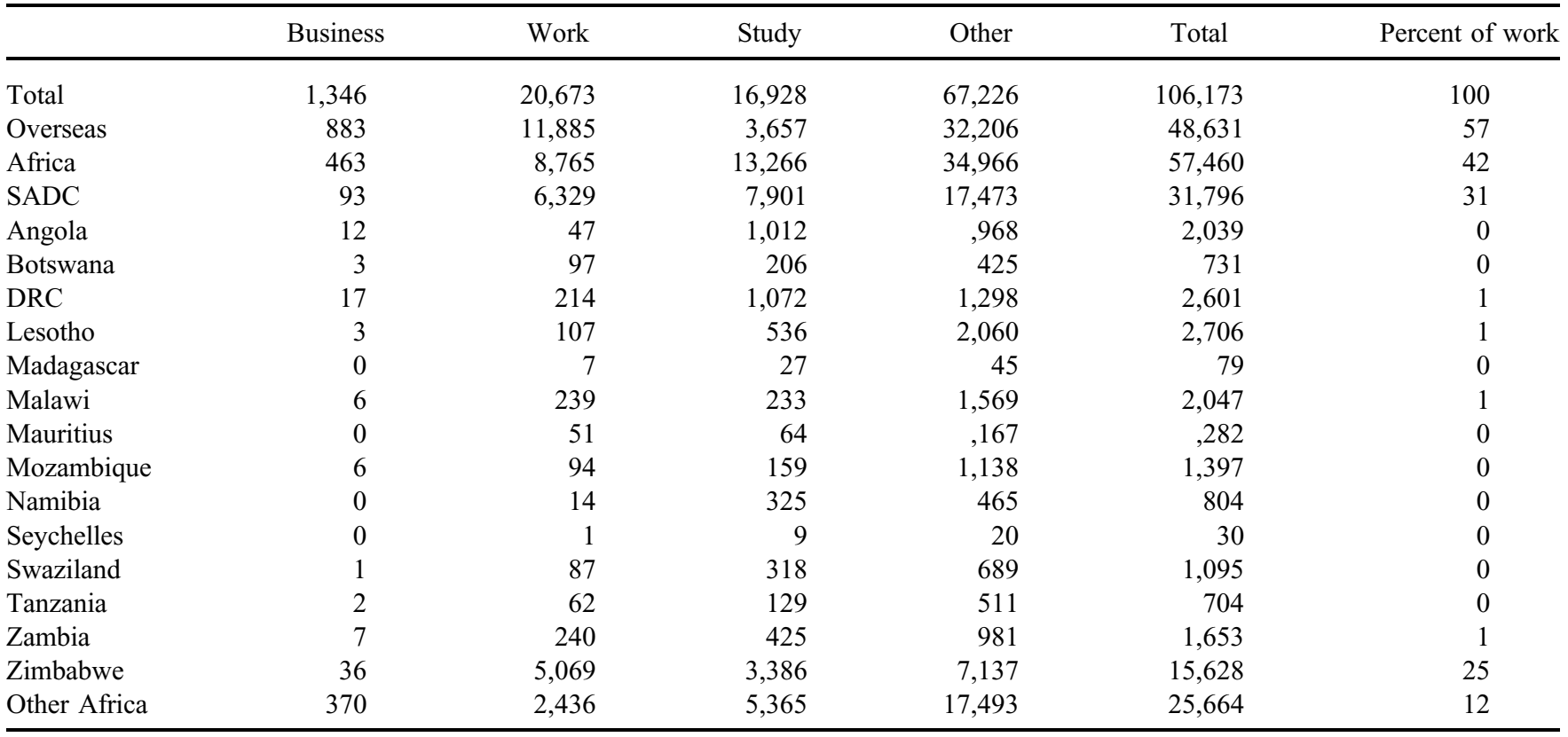

Source: Statistics South Africa in Budlender (2013).

South African citizens or permanent residents' spouses and children qualify for permanent residence. Investors in businesses considered in the national interest and those with certain amounts of capital also qualify. Table 6 shows the number of such permits issued (and for people permanently leaving South Africa) from 1980 to 2003. Although DHA issues them to permanently employed foreigners too, Table 6 does not show how many such permits were for employment purposes.

Post-apartheid South Africa's deportation scheme ranks among the world's largest. The immediate post-apartheid regime adopted a 'detain and deport' strategy for undocumented migrants, which achieved 180,000 deportations per annum in 1999 and, by 2007, had over 1.5 million deportees (Crush and Dodson, 2007, p. 446). Between 1988 and 2010 South Africa deported approximately 2.5 million people. Most deportees were SADC citizens and especially Mozambicans and Zimbabweans.

Barring massive deportations, adjustments in South Africa's immigration policies facilitated the formalization of many undocumented migrants in South Africa. In 2010 South Africa devised the Documentation of Zimbabweans Project (DZP) to legalize Zimbabweans that had come without official documentation. The DHA deviated from its targeted 224,000 deportations

Table 4: New SADC applicants for refugee status, 2011

\begin{tabular}{lr}
\hline Country of origin & Number of applicants \\
\hline Zimbabwe & 51,031 \\
DRC & 7,668 \\
Malawi & 3,774 \\
Mozambique & 560 \\
Tanzania & 473 \\
Zambia & 193 \\
Lesotho & 185 \\
Swaziland & 101 \\
Angola & 24 \\
Botswana & 2 \\
Namibia & 1 \\
Total & 64,012 \\
\hline
\end{tabular}

Source: DHA in Budlender (2013). 
Table 5: Work permits issued by the DHA, 1990-2011

\begin{tabular}{lrcr}
\hline Year & New permits & Renewals & Total \\
\hline 1990 & 7,657 & 30,915 & 38,571 \\
1991 & 4,117 & 32,763 & 36,880 \\
1992 & 5,581 & 33,318 & 38,899 \\
1993 & 5,741 & 30,810 & 36,551 \\
1994 & 8,714 & 29,352 & 38,066 \\
1995 & 11,053 & 32,838 & 43,891 \\
1996 & 19,498 & 33,206 & 52,704 \\
1997 & 11,361 & 17,129 & 28,490 \\
1998 & 10,828 & 11,207 & 22,035 \\
1999 & 13,163 & 10,136 & 23,299 \\
2000 & 6,643 & 9,191 & 15,834 \\
2004 & 4,185 & - & - \\
2006 & 17,205 & - & - \\
2007 & 19,601 & - & - \\
2008 & 32,344 & - & - \\
2009 & - & - & - \\
2010 & 5,926 & - & - \\
\hline
\end{tabular}

Source: Peberdy in Budlender (2013).

Table 6: Permanent resident permits and emigrants, 1980-2003

\begin{tabular}{|c|c|c|c|}
\hline Year & Immigrants & Emigrants & Net gain/loss \\
\hline 1981 & 41,542 & 8,791 & $+32,751$ \\
\hline 1983 & 30,483 & 8,247 & $+22,236$ \\
\hline 1984 & 28,793 & 8,550 & $+20,243$ \\
\hline 1985 & 17,284 & 11,401 & $+5,883$ \\
\hline 1987 & 7,953 & 11,174 & $-3,221$ \\
\hline 1988 & 10,400 & 7,767 & $+2,633$ \\
\hline 1989 & 11,240 & 4,911 & $+6,359$ \\
\hline 1990 & 14,499 & 4,722 & $+9,777$ \\
\hline 1991 & 12,379 & 4,256 & $+8,123$ \\
\hline 1992 & 8,686 & 4,289 & $+4,397$ \\
\hline 1997 & 4,103 & 8,946 & $-4,843$ \\
\hline 1998 & 4,371 & 8,276 & $-3,905$ \\
\hline 1999 & 3,669 & 8,487 & $-4,818$ \\
\hline 2000 & 3,053 & 10,262 & $-7,209$ \\
\hline 2001 & 4,832 & 12,260 & $-7,428$ \\
\hline 2002 & 6,545 & 10,890 & $-4,345$ \\
\hline 2003 & 10,578 & 16,165 & $-5,587$ \\
\hline
\end{tabular}

Source: Adapted from Peberdy in Budlender (2013). 
in 2010/2011 to an actual 58,825 because the DZP benefited many Zimbabweans, who previously constituted the bulk of deportations (Department of Home Affairs, 2011, p. 42). The number of temporary and permanent residence permits issued over the same period deviated from the target 80,000 to 239,992 because of the DZP (2011, p. 42). ${ }^{3}$ The Mozambicans that entered South Africa in the 1980s during the Mozambican civil war remained unclassified prior to 1993, because South Africa did not officially recognize refugees then (Schachter, 2009, p. 6). The DHA regularized these Mozambicans in 2000, after South Africa revised its stance on refugees. Mozambicans and Zimbabweans have benefited from at least one of the four South African Government amnesties to SADC-originating undocumented migrants since 1994. The 1996 amnesty was broadest, catering for all SADC citizens living in South Africa who had entered prior to 1 July 1991 (Mengelkoch, 2001). South Africa also gave amnesty within this period specifically to Mozambican refugees who did not qualify for the SADC amnesty (Peberdy, 2009).

South African immigration regulations today are more stringent and discourage (especially unskilled) 'illegal' immigration. Despite this, South Africa is apparently pursuing a less exclusionary policy towards skilled migrants than before. Immigration Acts 2002 and 2004 reflects this, out of concern over skills shortages and the rate at which professionals are emigrating (Table 6; Perberdy, 2009, p. 150). However, the actual number of work and business permits issued fall short of the Act's intentions. Table 6 shows that South Africa registered net losses of economically active people especially from 1995 up until 2003 - when the DHA stopped recording emigration, when Immigration Act of 2002 came into effect (Budlender, 2013).

\section{Bilateral Agreements and Labour Migration}

South Africa holds Joint Permanent Commissions of Cooperation with each of its SADC neighbours. The Cooperation Agreements between South Africa and Botswana, Lesotho and Swaziland, respectively, categorically stipulate among their objectives migration and facilitation of movement of people. The agreements between South Africa and Malawi, Mozambique, Zimbabwe and Namibia, respectively, do not specify migration among outlined objectives. The difference can be attributed to South Africa's historical relationship with Lesotho, Swaziland and Botswana in the SACU. Cooperation in migration is, nonetheless, implied in the general objectives of the agreements between South Africa and Namibia, Malawi, Mozambique and Zimbabwe, respectively. The Zimbabwe-South Africa Joint Commission for Economic, Social, Scientific, Technical and Cultural Co-operation, for example, does not specify migration but provides the framework in which Zimbabwe and South Africa have concluded Memoranda of Understanding (MOU) on Employment and Labour and on Cooperation and Mutual Assistance on Immigration Matters.

South Africa has long established labour MOUs with neighbours. The 24 December 1973 MOU with Botswana acknowledges arrangements existed from 1 July 1963 that governed the employment of Batswana in South Africa and the movement of persons across their common borders. The MOU establishes a Government of Botswana Labour Representative's Office in South Africa. The Office, among others, consults on employment-related matters of Batswana in South Africa; entry compliance, identification and documentation requirements; remittances and workers' welfare funds regarding Batswana working in South Africa; assists with the repatriation of sick, injured or destitute Batswana formerly employed and others unlawfully present in South Africa; etc. (Republic of South Africa, 1973). South Africa holds similar MOUs with Lesotho, Mozambique and Swaziland, respectively. Such agreements have guided labour migration in Southern Africa since their signing (Nshimbi and Fioramonti, 2013). Ex- and migrant miners associations of Lesotho, Mozambique and Swaziland Executives indicated that labour MOUs between South Africa and their respective countries were signed to regulate migration for labour into South African mines (Focus group discussion with: Mr Vama Jele, Treasurer, Swaziland Migrant and Mineworkers Association; Mr Rantso Mantsi, President, ExMiners Association of the Mountain Kingdom of Lesotho; and Mr Moises Uamusse, President, Association for Mozambican Miners (AMIMO), Protea Hotel Hatfield, 17 January 2013). Similar agreements in agriculture and domestic work, for example, are absent, although South African farmers in the Northern Province continued employing Zimbabwean labourers under 'the special agricultural permits' in 1994 (Minaar, 1996, p. 121). Bilateral agreements between South Africa and neighbours, therefore, govern migration in southern Africa. Men seeking work in mines and commercial farms constitute the longest-standing international labour migrants within southern Africa and to South Africa. Migration in these sectors is institutionalized because of established recruitment systems and TEBA's involvement.

\section{Key Aspects of Labour Migration Governance in SADC}

The SADC Treaty and Facilitation Protocol provide conditions for a southern African regional migration governance framework. The Treaty clearly envisions free regional movement of labour, capital, goods and services. Though not yet enforced, the 
Facilitation Protocol takes cognizance of and supports the AU's goal of an AEC by 2028. SADC labour migration objectives are achievable on three conditions.

\subsection{Instruments for Instituting Regional Migration Governance Systems}

Regions that have established regional labour migration governance systems are all founded on regional instruments that inform the type of migration governance frameworks in those regions (Nshimbi and Fioramonti, 2013). Where regional treaties do not specifically address labour migration, regions commission special committees to establish measures towards addressing regional labour migration (Nshimbi and Fioramonti, 2013).

South Africa holds labour MOUs with each of its seven neighbours discussed. The contents of the MOUs between South Africa and respective SACU states are essentially the same. SACU states could, under the SACU umbrella, formalize a regional labour migration system upon which to harmonize labour migration policies. This is plausible because the MOUs have long facilitated recruitment, especially for South African mines and agriculture. MOUs such as the Establishment of Labour Office between South Africa and the respective SACU states, however, seem unilateral and biased towards South Africa.

The non-enforcement of the Facilitation Protocol casts doubts over SADC's determination to achieve a Common Market. Focus and objective application of practical measures helped the EU realize freedom of movement of persons, capital, goods and services despite the challenges faced as the project evolved towards the Common Market. Economic and security concerns arise when sovereign states open their borders. Rather than let them impede integration, these are opportunities for States to jointly address the concerns. Structures have evolved around the coal and steel mines - the foundation of European integration including the EU's law enforcement agency, the European Police Office (Europol), established under the Maastricht Treaty. Jointly addressing regional public goods such as security can enhance regional integration.

\subsection{Pragmatic Handling of Labour Migration Provisions in the Treaties}

SADC's lack of a formal system to govern labour migration negatively impacts the AU's AEC targeted for 2028. In adopting the MPFA, African leaders demonstrated their agreement, in principle, with the document's principles and guidelines. The current absence of a regional migration protocol in SADC, however, shows members are not ready to implement the basic MFPA guidelines. The EU has realized free movement of persons through actual implementation of successive treaties, directives, and European Court of Justice rulings, etc. (Nshimbi and Fioramonti, 2013). Unlike SADC dropping the Free Movement of Persons Protocol, each successive EU instrument has enhanced free movement of EU citizens. SADC is saluted, however, for adopting the SADC Regional Labour Migration Action Plan 2013-2015 in April and July 2013 (Nshimbi, 2013), the results of whose implementation should be seen after 2015 .

\subsection{Compromise between Member States' Sovereignty and Regional Realities}

European integration has so progressed that members surrender aspects of their sovereignty to supranational regional institutions. EU law is superimposed on national laws of individual member states and brings accompanying obligations and rights. Member states domesticate EU laws and policies. The contrary obtains in the SADC region. South Africa's amnesties to Zimbabweans, Mozambican refugees and SADC citizens were one-off measures implemented by a single state and not a regional agreement. An established regional migration governance system rather than ad hoc measures during crisis will serve SADC better.

\section{Conclusions and Recommendations}

Southern Africa is a porous region with substantial informal cross-border movements. Some of the issues associated with unmanaged migration processes here include brain drain, downward pressures on wages and frictions between migrants and locals in host countries. Although most of these problems have existed for a longer period, current events - such as attacks on migrants in South Africa - make it paramount to address regional migration with a clear regional framework. Regularizations by no means provide the type of sustainable legal framework needed to manage regional migration effectively, let alone guarantee the basic forms of protection for migrant workers. The lack of a clear regional framework is also triggering continuous 
repatriations and 'emergency measures' such as forced deportations, which cost the South African government, while showing no effectiveness at controlling undocumented migration inflows. Most of the undocumented migrants that are deported from South Africa return, once again, via informal routes.

Bilateralism currently governs migration in the SADC region. This form of bilateralism, however, is exclusive. It does not take into consideration the interests of other countries, but isolates the contracting parties from the regional context, often forcing them to compete with one another. Such exclusive bilateralism crystallizes the negotiating parties into two fixed categories sending and receiving countries - thereby resulting in a zero-sum game. The payoffs of sending countries are seen as losses for the receiving countries. South Africa may still be the major destination of SADC-originating migrant labour, but also sends workers and business people to SADC countries (e.g. Botswana). A regional policy framework would highlight this integrated element of labour migration and therefore open up possibilities for a more cohesive and mutually beneficial system of management.

The following policy recommendations are based on overall findings and highlighted issues.

- The SACU should be seen as a policy laboratory, where new innovations could be introduced before considering a potential/ incremental expansion to the SADC region. SACU members should, therefore, establish a two-tier policy whereby they work towards free movement of labour while maintaining a managed migration policy outside of SACU, within SADC, or within the CEST region.

- If bilateralism is the only workable practice, SADC states should emphasize forms of bilateralism that take regional elements into account not exclusive bilateralism. Bilateralism should be encouraged only if it is incremental and used as a steppingstone towards establishing a regional framework for migration (e.g. it should be compatible with and supportive of policies being discussed at the SADC level). Where bilateral agreements already exist, therefore, the agreements should be redesigned in order to support regional policies rather than undermine them.

\section{Notes}

1. These include the Community of Sahel-Saharan States (CEN-SAD), Economic Community of Central African States (ECCAS), COMESA, Intergovernmental Authority for Development (IGAD), SADC, Union du Maghreb Arabe (UMA). See http://www.au.int/en/recs/. Retrieved 26 November 2012.

2. Angola, Botswana, the DRC, Lesotho, Madagascar, Malawi, Mauritius, Mozambique, Namibia, Seychelles, South Africa, Swaziland, Tanzania, Zambia and Zimbabwe. SADCC founding members included five Frontline States (FLS) namely Angola, Botswana, Mozambique, Tanzania and Zambia, plus Lesotho, Malawi and Swaziland.

3. The number only reflects those permits in the Track and Trace System which became fully utilized from July 2010 (DHA, 2011, p. 42 footnote).

\section{References}

African Union (AU) (2006a), The Migration Policy Framework for Africa, Executive Council, Ninth Ordinary Session, Banjul, The Gambia, 25-29 June.

African Union (AU) (2006b), African Common Position on Migration and Development, Executive Council, Ninth Ordinary Session, Banjul, The Gambia 25-29 June.

African Union (AU) (2012), Regional Economic Communities (RECs): Union de Maghreb Arabe (UMA), Available at: www. africa-union.org/root/au/recs/uma.htm (accessed 28 August 2012).

Asiedu, E. and K. Gyimah-Brempong (2008), 'The Effect of the Liberalization of Investment Policies on Employment and Investment of Multinational Corporations in Africa', African Development Review, Vol. 20, No. 1, pp. 49-66.

Budlender, D. (2013), MiWORC Report No. 2, Improving the Quality of Available Statistics on Foreign Labour in South Africa: Existing Data-sets, African Centre for Migration and Society, University of the Witwatersrand, Johannesburg. 
COMESA-EAC-SADC Tripartite (2012), The Final Communique of the First COMESA-EAC-SADC Tripartite Summit, 20 October 2008 in Kampala, Uganda. Available at: www.comesa-eac-sadc-tripartite.org/node/78 (accessed 29 August 2012).

Crush, J. and B. Dodson (2007), 'Another Lost Decade: The Failures of South Africa's Post-Apartheid Migration Policy', Tijdschrift voor Economische en Sociale Geografie, Vol. 98, No. 4, pp. 436-54.

Department of Home Affairs (2011), Department of Home Affairs Annual Report 2010/11, Department of Home Affairs, Pretoria.

Klaaren, J. and B. Rutinwa (2004), 'Towards the Harmonization of Immigration and Refugee Law in SADC', MIDSA Report, No. 1, Idasa, Cape Town.

Mengelkoch, S. (2001), The Right to Work in SADC Countries, Nomos Verlagsgesellschaft, Baden-Baden.

Minaar, A. (1996), 'Illegal Aliens/Migrants in Zimbabwe', in A. Minaar and M. Hough (eds.), Who Goes There? Perspectives on Clandestine Migration and Illegal Aliens in South Africa, HSCR Publishers, Pretoria.

Nita, S. (forthcoming), 'Regional Free Movement of People: The Case of African Regional Economic Communities', in Regions and Cohesion: Special Edition, UNESCO-UNU Chair on Regional Integration, Migration and Free Movement of People.

Nshimbi, C. (2013), State of Denial, available at: www.opendemocracy.net/chris-nshimbi/state-of-denial (accessed 16 December 2013).

Nshimbi, C. C. and L. Fioramonti (2013), MiWORC Report No. 1 A Region without Borders? Policy Frameworks for regional Labour Migration towards South Africa, African Centre for Migration and Society, University of the Witwatersrand, Johannesburg.

Onyeiwu, S., R. I. Polimeni and J. M. Polimeni (2008) ‘Distributional Impact of Globalization-induced Migration: Evidence from a Nigerian Village', African Development Review, Vol. 20, No. 1, pp. 114-33.

Oucho, J. O. and J. Crush (2001), 'Contra Free Movement: South Africa and the SADC Migration Protocols', Africa Today, Vol. 48, No. 3, pp. 138-58.

Peberdy, S. (2009), Selecting Immigrants: National Identity and South Africa's Immigration Policies 1910-2008, Wits University Press, Johannesburg.

Republic of South Africa (1973), Agreement between the Government of the Republic of South Africa and the Government of the Republic of Botswana relating to the Establishment of an Office for a Botswana Government Labour Representative in South Africa, Botswana Citizens in the Republic of South Africa and the Movement of Such Persons across the International Border, Treaty Series, No. 3, Government Printer, Pretoria.

SADC (2003), Regional Indicative Strategic Development Plan, Southern African Development Community, Gaborone.

SADC (2012a), Draft Protocol on the Facilitation of Movement of Person, available at: www.sadc.int/english/key-documents/ protocols/protocol-on-the-facilitation-of-movement-of-persons/ (accessed 26 July 2012).

SADC (2012b), Protocol on Trade, available at: www.sadc.int/index/browse/page/161 (accessed 26 July 2012).

Schachter, J. P. (2009), Data Assessment of Labour Migration Statistics in the SADC Region: South Africa, Zambia, Zimbabwe, International Organization for Migration (IOM).

Statistics South Africa (2013), Documented Immigrants in South Africa, 2012, Statistics South Africa, Pretoria.

United Nations (2012), International Migration and Development Report of the Secretary-General, A/67/254, 67th Session (2012-2013), United Nations, New York.

United Nations Department of Economic and Social Affairs, Population Division. (2012), Population Facts No. 2012/3, June, United Nations, New York. 